\title{
Hepatic Calyptospora sp. (Apicomplexa) infection in a wild-born, aquarium-held clutch of juvenile arapaima Arapaima gigas (Osteoglossidae)
}

\author{
Christopher J. Bonar ${ }^{1,2, *}$, Sarah L. Poynton ${ }^{3,4}$, F. Yvonne Schulman ${ }^{4}$, \\ Randall L. Rietcheck ${ }^{5}$, Michael M. Garner ${ }^{6}$ \\ ${ }^{1}$ Cleveland Metroparks Zoo, 3900 Wildlife Way, Cleveland, Ohio 44109, USA \\ ${ }^{2}$ The Cleveland Aquarium Incorporated, 8871 Camelot Drive, Chester Township, Ohio 44026, USA \\ ${ }^{3}$ Department of Molecular and Comparative Pathobiology, Johns Hopkins University School of Medicine, \\ 733 North Broadway, Baltimore, Maryland 21205, USA \\ ${ }^{4}$ Leibniz Institute of Freshwater Ecology and Inland Fisheries, Müggleseedamm 310, 12587 Berlin, Germany \\ ${ }^{5}$ Armed Forces Institute of Pathology, Washington, DC 20306, USA \\ ${ }^{6}$ Northwest ZooPath, 654 West Main, Monroe, Washington 98272, USA
}

\begin{abstract}
From Manaus, Brazil, 12 juvenile arapaima Arapaima gigas were imported to the United States and sent to 2 public aquaria, 1 private hobbyist, and 1 retailer. All 12 fish became ill within 4 to 6 wk of arrival, with signs of anorexia, lethargy, depigmentation, and ascites, and subsequently died despite antibiotic and anthelminthic therapy. Gross necropsies of 7 fish revealed serosanguinous coelomic effusion in all 7 fish, and branchial monogeneosis in 3 of 6 fish. The monogeneans from 1 fish were identified as Dawestrema cycloancistrium (Ancyrocephalinae). Histologic examination of 7 fish showed a variety of lesions, principally in the liver, gills, brain and gastro-intestinal tract. Numerous coccidian oocysts replaced 15 to $33 \%$ of the liver parenchyma in 6 of 7 fish examined. Light and transmission electron microscopy revealed that each oocyst contained 4 pyriform sporocysts bearing numerous sporopodia on their tapering, posterior end; approximately 25 to $30 \%$ of the length of the sporocyst was adorned. Each sporocyst was covered by a thin, membranous veil, contained 2 sporozoites, and stained brilliant pink with the Ziehl-Neelsen acid-fast method. This morphology is consistent with that of Calyptospora sp. (Lack of fresh material precluded determination to species.) This is the first report of Calyptospora sp. in arapaima. The Calyptospora sp. infection probably contributed to the morbidity and mortality of the captive arapaima.
\end{abstract}

KEY WORDS: Arapaima gigas $\cdot$ Branchitis $\cdot$ Calyptospora $\cdot$ Dawestrema $\cdot$ Liver

Resale or republication not permitted without written consent of the publisher

\section{INTRODUCTION}

The pirarucu, or arapaima, Arapaima gigas (Osteoglossidae), is a highly sought-after food fish of the Amazon basin. It is also the largest, strictly freshwater fish in the world, attaining over $2.5 \mathrm{~m}$ in length, and is highly prized as a public aquarium specimen (Nelson 1984, Casares et al. 2002). Overfishing of the species for food has made it scarce throughout its range, and has resulted in it being listed as endangered by the United States Fish and Wildlife Service. The arapaima is listed in Appendix II-B of the Convention on the International Trade in Endangered Species (CITES) (Casares et al. 2002). This fish, however, has excellent promise as a candidate for aquaculture because it attains breeding size in 1 season, spawns readily in shallow ponds, and grows rapidly on less valuable fishes such as Tilapia spp.

Despite the importance of arapaima as a valuable food fish, a desirable aquarium specimen, and an endangered species, little has been published on its diseases. The protozoan fauna of neotropical fishes, 
including the arapaima, is much less well known than the metazoan fauna; in a host-parasite check list of Amazonian fishes, no protozoans were listed from the arapaima, in contrast to the 16 species of metazoans including helminths and crustaceans (Thatcher 1991). The present paper describes an outbreak of hepatic protozoal infection caused by a species of Calyptospora (Apicomplexa) in a group of juvenile arapaima from Brazil.

Previously, 4 (or possibly 5) species of Calyptospora have been reported from fishes, including 2 species from South American hosts: C. serrasalmi from the liver and intrahepatic pancreatic acinar cells of aquarium-held black piranha Serrasalmus niger (Cheung et al. 1986), and C. tucunarensis from the liver of wild and farmed tucunare Cichla ocellaris from Brazil (Békési \& Molnár 1991). Calyptospora spp. infections can cause a variety of lesions, including grayish spots on the liver lobes (Cheung et al. 1986), severe degeneration of the liver (Békési \& Molnár 1991), and replacement of up to $85 \%$ of the liver and pancreas (Solangi \& Overstreet 1980).

The present paper is the first report of Calyptospora sp. (Apicomplexa) in arapaima, and the infection appeared to contribute to morbidity and mortality in this threatened and economically important fish.

\section{MATERIALS AND METHODS}

Source of fish. In March 2001, a group of 10 to $15 \mathrm{~cm}$ long, juvenile arapaimas was imported (with appropriate Convention on International Trade in Endangered Species [CITES] permits) from Manaus, Brazil, by a Florida importer, and then sent to a New York wholesaler for shipment throughout the United States. Our study group of 12 of these fish consisted of 9 fish that were shipped from New York to a local Cleveland retailer, and 3 fish shipped directly from New York to a Texas public aquarium. Of the 9 fish sent to the Cleveland retailer, 3 were purchased and maintained in a private aquarium, 3 were sent to another Texas public aquarium, and 3 remained at the retailer.

Case histories, necropsies and histopathology. After all 12 of these fish had died, their case histories were collected. Gross necropsy results were recorded for 7 fish, and histopathology was performed in all 7 cases ( 3 from the private collector and 4 from the Texas public aquaria). Tissue samples were preserved in $10 \%$ neutral buffered formalin, processed routinely, paraffin embedded, sectioned at $5 \mu \mathrm{m}$, and stained with hematoxylin and eosin. Additional liver sections were stained with the Ziehl-Neelsen acid-fast method to reveal more detail of the sporocyst wall of the coccidian, and to facilitate the morphometrics. The percentage of liver effaced by the oocysts was calculated by examination of histologic sections examined at $400 \times$ magnification using a digital image analysis program (NIH image, United States National Institutes of Health).

Parasitology: light microscopy. Sporocysts of the Calyptospora species from Arapaima gigas closely resembled both C. serrasalmi and C. tucunarensis; therefore, type material from these 2 previously described species was studied for comparison. For C. serrasalmi, we obtained acid-fast, air-dried smears from the United States National Museum of Natural History (USNM), Accession No. 32843, from which the type description was made and designated as syntypes by Cheung et al. (1986); wet tissue and histological sections were no longer available. For C. tucunarensis, we obtained paraffin-embedded tissue from the original investigator, Dr. K. Molnar, of the Veterinary Medical Research Institute, Budapest, Hungary, designated as syntypes in the type description by Békési \& Molnár (1991). We cut new sections, and stained them with Ziehl-Neelsen acid-fast stain (the type description was based on sporulated oocysts in fresh preparation; sectioned material stained with hematoxylin and eosin was also originally studied).

Parasitology: electron microscopy. For ultrastructural studies, liver was deparaffinized, hydrated and post-fixed in $1 \%$ osmium tetroxide, dehydrated, cleared and embedded in epoxy resin. We cut $1 \mu \mathrm{m}$ sections and stained them in toluidine blue for preliminary light microscope examination. Thin sections $(80$ to $90 \mathrm{~nm}$ ) were cut and stained with uranyl acetate and lead citrate, and were examined with a Zeiss EM10 transmission electron microscope.

\section{RESULTS}

\section{Case history and clinical signs}

The 3 fish that went to the private collector acclimated well, and began to feed on live goldfish Carassius auratus almost immediately. Over the course of the next month, each fish successively began to show signs of lethargy, color loss, anorexia and mild hyperpnea. Systemic bacterial infection and/or branchitis were suspected; therefore, Fish 1 and 3 were treated with injections of ceftazidime (Fortaz, GlaxoSmithKline, Research Triangle Park) at a dosage of $20 \mathrm{mg} \mathrm{kg}^{-1}$, intracoelomically $\mathrm{q} 48 \mathrm{~h}$. Fish 2 was treated with enrofloxacin (Baytril) at $5 \mathrm{mg} \mathrm{kg}^{-1}$, intracoelomically, q48 $\mathrm{h}$. The antibiotics had little effect in ameliorating the clinical signs, and all 3 fish died within 2 to $5 \mathrm{~d}$ of onset of the illness.

Fish 4, 5 and 6 (sent to a Texas public aquarium) displayed similar clinical signs of illness. After Fish 4 had died (10 d after arrival), Fish 5 and 6 were treated 
empirically with praziquantel (Droncit) in an indefinite, prolonged immersion bath $\left(3 \mathrm{mg} \mathrm{l}^{-1}\right)$ for branchial monogeneans. Fish 5 died, and Fish 6 was treated for monogeneans a second time with trichlorfon (Dylox) also in an indefinite, prolonged immersion bath $\left(0.25 \mathrm{mg} \mathrm{l}^{-1}\right)$ and survived for approximately 3 more weeks before dying.

Fish 7, 8 and 9 (which had remained at the retailer's) died within $1 \mathrm{wk}$ of arrival without treatment, and were not submitted for necropsy.

Fish 10, 11 and 12 (shipped directly from New York to another large Texas public aquarium) developed similar signs of illness, including anorexia, hyperpnea, depigmentation and ascites, and died abruptly, before treatment could be initiated, within approximately 2 wk of arrival.

\section{Pathology}

Gross necropsy of 7 fish revealed serosanguinous coelomic effusion in all 7, and branchial monogeneosis in 3 of the 6 fish for which gill tissue was available for examination.

Histological examination of 7 fish revealed a variety of lesions, principally in the liver, gills, brain and gastro-intestinal tract (Table 1). In the livers of 6 of the 7 , there were numerous coccidian oocysts that contained sporocysts and sporozoites (Calyptospora sp.), and occupied 15 to $33 \%$ of the hepatic mass (Fig. 1) as determined by digital image analysis of bright field photomicrographs taken at $400 \times$ magnification. No appreciable inflammation was associated with the parasites.

Table 1. Calyptospora spp. Ecological data and comparative morphometrics. Measurements are ranges and (mean). nd: not determined

\begin{tabular}{|c|c|c|c|c|c|c|c|}
\hline $\begin{array}{l}\text { Species } \\
\text { Host location }\end{array}$ & $\begin{array}{l}\text { Geographic locality } \\
\text { of origin }\end{array}$ & $\begin{array}{l}\text { Oocyst } \\
\text { diam. }\end{array}$ & Shape & - Sporocyst & $\overline{\text { Width }(\mu \mathrm{m})}$ & $\begin{array}{l}\text { Sporopodia number, } \\
\text { location morphology }\end{array}$ & Source \\
\hline \multicolumn{8}{|l|}{ C. empristica ${ }^{\mathrm{a}}$} \\
\hline $\begin{array}{l}\text { Starhead topminnow } \\
\text { Fundulus notti } \\
\text { (Cyprinodontidae): } \\
\text { Liver }\end{array}$ & $\begin{array}{l}\text { Mississippi, USA: } \\
\text { freshwater }\end{array}$ & $19.6-24.5$ & $\begin{array}{l}\text { Ellipsoid } \\
(22.3)\end{array}$ & $\begin{array}{l}7.0-9.5 \\
(9.0)\end{array}$ & $\begin{array}{l}4.5-7.5 \\
(5.4)\end{array}$ & $\begin{array}{l}\mathrm{n}=1, \\
\text { posterior narrow } \\
\text { pole, } 5-7 \mu \mathrm{m}(5.7 \mu \mathrm{m}) \\
\text { long, ornamented with } \\
\text { lateral projections } \\
0.5 \mu \mathrm{m} \text { long, terminating } \\
\text { in knob-like swellings }\end{array}$ & $\begin{array}{l}\text { Fournie et al. } \\
\text { (1985) }\end{array}$ \\
\hline $\begin{array}{l}\text { C. funduli } \\
\text { Gulf killifish } \\
\text { Fundulus grandis } \\
\text { (Cyprinodontidae): } \\
\text { Liver }\end{array}$ & $\begin{array}{l}\text { Mississippi, USA: } \\
\text { estuarine }\end{array}$ & $\begin{array}{c}20-31 \\
(25)\end{array}$ & Ovoid & $\begin{array}{c}9-11 \\
(10)\end{array}$ & $\begin{array}{l}5-7 \\
(6)\end{array}$ & $\begin{array}{l}\mathrm{n}=10-25 \\
\text { entire surface, } \\
\text { expanded distal } \\
\text { portion }\end{array}$ & $\begin{array}{l}\text { Duszynski et al. } \\
\text { (1979) }\end{array}$ \\
\hline $\begin{array}{l}\text { C. serrasalmic } \\
\text { Black piranha } \\
\text { Serrasalmus niger } \\
\text { (Characidae): } \\
\text { Liver }\end{array}$ & $\begin{array}{l}\text { Amazon: } \\
\text { freshwater }\end{array}$ & $\begin{array}{l}22-25 \\
(23.8)\end{array}$ & Pear-shaped & $\begin{array}{c}10.0-11.5 \\
(11.0)\end{array}$ & $\begin{array}{l}5-6 \\
(5.7)\end{array}$ & $\begin{array}{l}\mathrm{n}=8-10 \\
\text { pointed end, } \\
0.5 \mu \mathrm{m} \text { long }\end{array}$ & $\begin{array}{l}\text { Cheung et al. } \\
(1986)\end{array}$ \\
\hline $\begin{array}{l}\text { C. } \text { tucunarensis }^{\mathrm{d}} \\
\text { Tucunare } \\
\text { Cichla ocellaris } \\
\text { (Cichlidae): } \\
\text { Liver }\end{array}$ & $\begin{array}{l}\text { Brazil; Amazon: } \\
\text { freshwater }\end{array}$ & $\begin{array}{l}23-26 \\
(24.3)\end{array}$ & $\begin{array}{l}\text { Frying-pan, } \\
\text { ellipsoid } \\
\text { body }\end{array}$ & $\begin{array}{l}7.2-9.1 \\
(8.3)\end{array}$ & $\begin{array}{l}3.5-5.0 \\
(3.7)\end{array}$ & $\begin{array}{l}\mathrm{n}=1 \\
\text { posterior end, } \\
2.5-2.9 \mu \mathrm{m} \\
(2.7 \mu \mathrm{m}) \text { long }\end{array}$ & $\begin{array}{l}\text { Békési \& Molnár } \\
\text { (1991) }\end{array}$ \\
\hline $\begin{array}{l}\text { E. harpondi } \\
\text { Bombay duck } \\
\text { Harpodon nehereus } \\
\text { (Synodontidae): } \\
\text { Intestine }\end{array}$ & $\begin{array}{l}\text { India: } \\
\text { marine and } \\
\text { estuarine }\end{array}$ & $\begin{array}{c}12-16 \\
(14)\end{array}$ & Elliptical & $\begin{array}{l}\text { nd } \\
(9.6)\end{array}$ & $\begin{array}{l}\text { nd } \\
(4.6)\end{array}$ & $\begin{array}{l}\mathrm{n}=1 \\
\text { polar, tipped with } \\
\text { inverted } \mathrm{v} \text {-shaped } \\
\text { appendage }\end{array}$ & $\begin{array}{l}\text { Setna \& Bana } \\
\text { (1935) }\end{array}$ \\
\hline $\begin{array}{l}\text { Calypsospora sp. } \\
\text { Arapaima (pirarucu) } \\
\text { Arapaima gigas } \\
\text { (Osteoglossidae): } \\
\text { Liver }\end{array}$ & $\begin{array}{l}\text { Brazil; Amazon: } \\
\text { freshwater }\end{array}$ & $\begin{array}{c}16-22 \\
(19)\end{array}$ & Pyriform & $\begin{array}{l}8-10 \\
(9)\end{array}$ & $\begin{array}{l}4-5 \\
(4)\end{array}$ & $\begin{array}{l}\text { numerous, } \\
\text { posterior narrow } \\
\text { pole, } 0.5 \mu \mathrm{m} \text { long }\end{array}$ & Present study \\
\hline $\begin{array}{l}{ }^{a} \text { From } 60 \text { sporulated or } \\
{ }^{b} \text { From } 100 \text { sporulated } \\
{ }^{c} \text { From } 10 \text { specimens fr } \\
{ }^{d} \text { From } 50 \text { sporulated o } \\
\text { e Number of measurem } \\
\text { not known } \\
{ }^{f} 20 \text { sporulated oocysts, }\end{array}$ & $\begin{array}{l}\text { ocysts in fresh squas } \\
\text { oocysts held in } 2 \% \text { a } \\
\text { rom Ziehl-Neelsen ac } \\
\text { ocysts in fresh prepa } \\
\text { nents unknown. Unce } \\
\end{array}$ & $\begin{array}{l}\text { h preparati } \\
\text { aq. } \mathrm{K}_{2} \mathrm{Cr}_{2} \mathrm{O}_{7} \\
\text { cid fast stair } \\
\text { arations } \\
\text { ertain affini } \\
\text { ehl-Neelsel }\end{array}$ & $\begin{array}{l}\text { ons } \\
\text { at } 4 \text { to } 5^{\circ} \mathrm{C} \text {. Or } \\
\text { ned air dried sr } \\
\text { tty with Calypt } \\
\text { acid-fast stair }\end{array}$ & $\begin{array}{l}\text { riginally desc } \\
\text { mears } \\
\text { tospora spp.; } \\
\text { ined histologi }\end{array}$ & $\begin{array}{l}\text { il not repor } \\
\text { l sections }\end{array}$ & d; intestinal location & al. (1979) \\
\hline
\end{tabular}




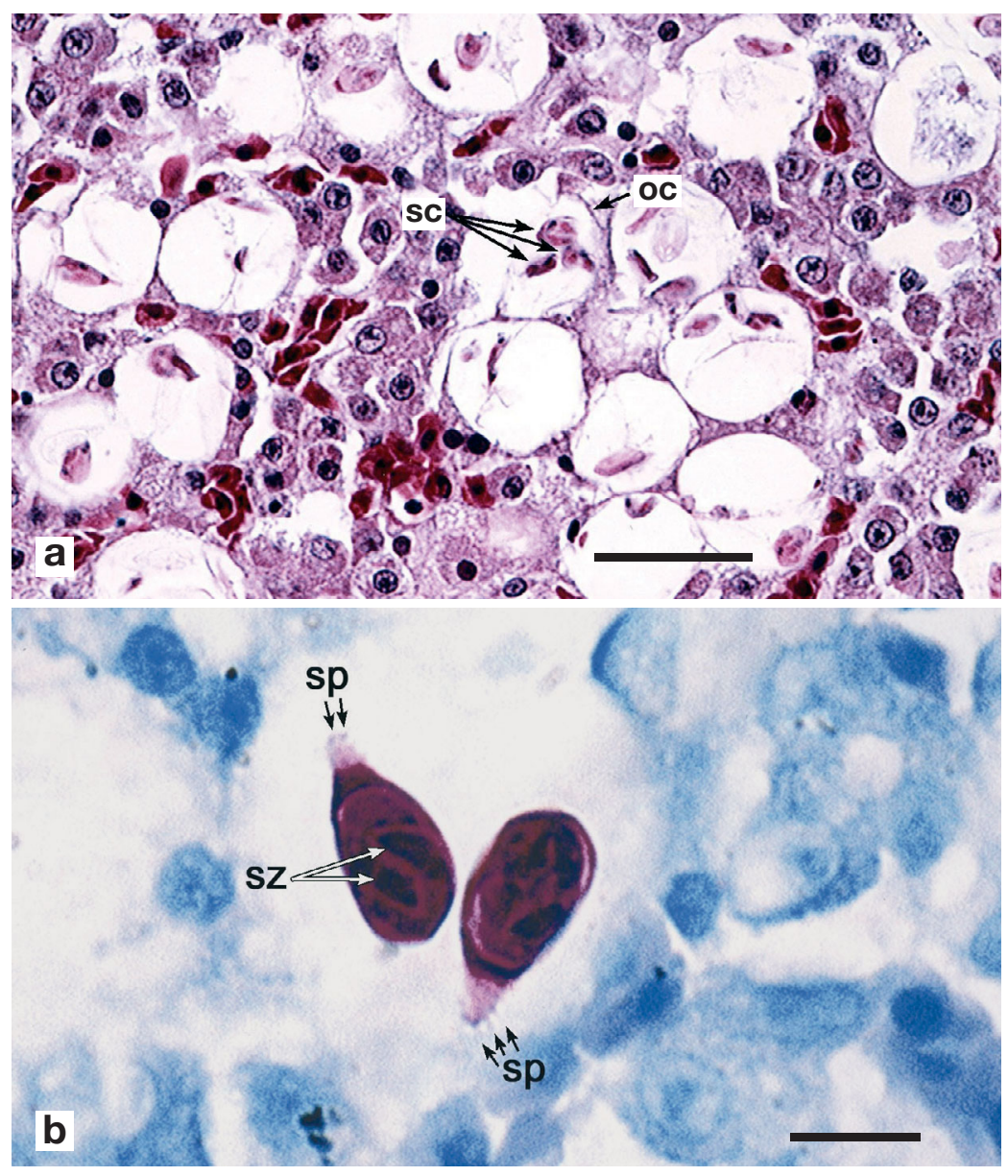

Fig. 1. Calyptospora sp. in liver of Arapaima gigas; histologic sections. (a) Thinwalled, spherical oocysts (oc) scattered throughout the hepatic parenchyma; morphology of the sporocysts (sc) is difficult to appreciate in this hematoxylin and eosin-stained section. Scale bar $=20 \mu \mathrm{m}$. (b) Oocysts containing pyriform sporocysts, each of which contains 2 sporozoites (sz), in head to tail configuration; note that sporocysts bear sporopodia (sp) on the narrow (posterior) onequarter to one-third of their surfaces. The morphology of the sporocysts is well defined in this Ziehl-Neelsen stained section. Scale bar $=5 \mu \mathrm{m}$

and nerve roots. In 1 case, there were also glial nodules in the spinal nerve ganglia. The cause and significance of these nervous system findings are not known.

All gastrointestinal tracts had multifocal, mild to moderate, granulocytic infiltrates in the lamina propria and submucosa. Of the 6 gastrointestinal tracts examined, 2 had a few adult nematodes in the serosa.

\section{Morphometrics of Calyptospora sp. from arapaima}

In histological section, the thinwalled oocysts scattered throughout the hepatic parenchyma were spherical, 16 to $22 \mu \mathrm{m}$ in diameter $($ mean = $1 \mu \mathrm{m}, \mathrm{n}=20$ ), and each contained 4 pyriform sporocysts with tapering posterior ends, each of which held 2 sporozoites (tetrasporocystic, dizoic) (Fig. 1, Table 1). The sporocysts stained brilliant fuschia pink with ZiehlNeelsen acid-fast stain. They were 8 to $10 \mu \mathrm{m}$ long $($ mean $=9 \mu \mathrm{m}, \mathrm{n}=20)$, and 4 to $5 \mu \mathrm{m}$ wide $(\operatorname{mean}=4 \mu \mathrm{m}, \mathrm{n}=20$ ), and had a dark staining crescentic region between the main body of the sporocyst and the posterior narrow extension. Sporocysts bore numerous sporopodia on the narrow, posterior end of the sporocyst, approximately 25 to $30 \%$ of the length of the sporocyst was adorned; the broader mid-region and anterior end were unadorned. Sporocysts were covered with a thin, veil-like

All 6 fish from which gills were available for histological examination had branchitis, and in 3 fish monogeneans were present between the lamellae (Fig. 2). Microscopic examination of whole stained mounts of 14 monogeneans from Fish 2 confirmed that all 14 were Dawestrema cycloancistrium (Ancyrocephalinae) (Kritsky et al. 1985). Although the branchial epithelium was often lost through to postmortem autolysis, epithelial proliferation was evident in 5 of the 6 fish, and the interstitium was multifocally mildly expanded by mononuclear cells and occasional granulocytes.

In all 4 fish from which brain was available for examination, there were aggregates of small to moderate numbers of granulocytes with round eosinophilic granules admixed with a few granulocytes with elongate granules in the meninges, submeningeal parenchyma membrane. A suture line appeared to be present in the spore wall. Within the sporocysts, the sporozoites were arranged head to tail, and each sporozoite bore 1 large red-staining mass (possibly lipid), and 1 smaller bluestaining mass (the nucleus), as observed in hematoxylin and eosin-stained sections.

\section{Morphology of Calyptospora serrasalmi from black piranha}

Re-examination of the type material, acid-fast stained, air-dried smears, showed that sporopodia were present over the narrow posterior end of the pyriform sporocyst (approximately 25 to $30 \%$ of the length of the sporocyst was adorned) (Table 1). In the type description 


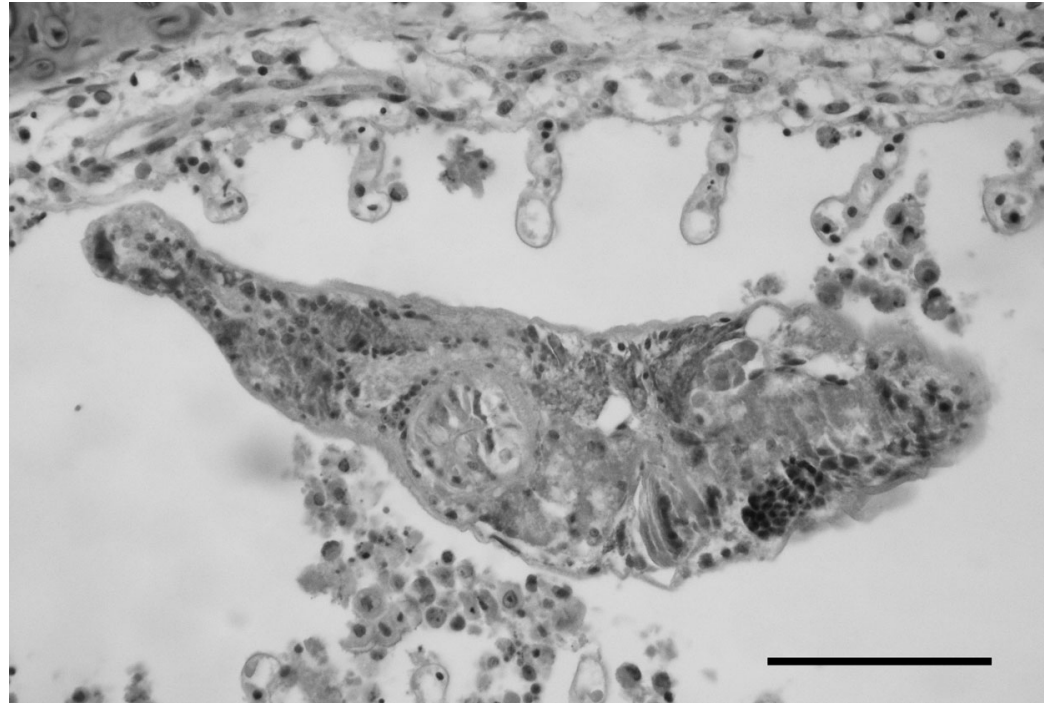

Fig. 2. Dawestrema cycloancistrium. Monogenean in interlamellar space of gills of Arapaima gigas, associated with exfoliated lamellar cells. H\&E. Scale bar $=225 \mu \mathrm{m}$

(Fig. 1 in Cheung et al. 1986) the line drawing showed sporopodia arising only laterally from, but not all around, the posterior end of the pyriform sporocyst; furthermore, they were depicted on only 15 to $20 \%$ of the length of the sporocyst.

\section{Morphology of Calyptospora tucunarensis from tucunare}

In newly cut histologic sections stained with ZiehlNeelsen acid-fast, thin-walled oocysts were clustered throughout the hepatic parenchyma. In the clusters, individual oocysts walls were often difficult to recognize. Oocysts were spherical, 16 to $20 \mu \mathrm{m}$ in diameter (mean $=19 \mu \mathrm{m}, \mathrm{n}=10$ ), and each contained 4 pyriform sporocysts, each of which held 2 sporozoites in head to tail arrangement (Table 1). The sporocysts were acidfast, 7 to $8 \mu \mathrm{m}$ long (mean $=7 \mu \mathrm{m}, \mathrm{n}=10$ ), and $4 \mu \mathrm{m}$ wide (mean $=4 \mu \mathrm{m}, \mathrm{n}=10$ ), and bore numerous sporopodia over their narrow posterior end (approximately 20 to $25 \%$ of the length of the sporocyst was adorned). In the type description (Békési \& Molnar 1991), sporopodia were not reported.

\section{Ultrastructure of Calyptospora sp. from arapaima}

Transmission electron microscopy confirmed that the thin membranous oocyst contained 4 sporocysts (Fig. 3), each of which was covered by a veil (Fig. 4) and contained 2 sporozoites (Fig. 5). For some sporo- cysts, the space between the veil and the surface of the sporocyst was electron lucent (Fig. 4), whereas for other sporocysts this space was filled with electron-dense, flocculent material (Fig. 5).

The most distinctive features of the sporocyst were the long extension at the posterior pole, formed by an approximately cylindrical extension of the sporocyst wall (Figs. 4 \& 6), and numerous cylindrical to club-shaped sporopodia, up to $0.5 \mu \mathrm{m}$ long and $0.125 \mu \mathrm{m}$ wide, borne perpendicular to the sporocyst surface on this and adjacent posterior regions (Figs. 4 \& 6). Occasionally, a suture was seen in the anterior sporocyst wall (Figs. 4 \& 7). The sporocyst wall was typically $0.125 \mu \mathrm{m}$ thick, except where giving rise to the posterior extension and the sporopodia. The wall consisted of a thin, outer, electron-lucent layer with an electron-dense coating, and a thick, inner, more electron-dense layer, with regular transverse striations (Fig. 8). The posterior extension of the sporocyst wall was lined by a thin lamella of electron-dense material, $0.075 \mu \mathrm{m}$ beneath the surface, which was possibly an extension of the electron-dense material that lay between the sporocyst wall and the sporozoites (Fig. 6). The sporopodia contained an electron-dense core (Fig. 6).

The sporocyst veil was 3-layered, with 2 electrondense layers (a thinner outer and a thicker inner) lying each side of an electron-lucent middle layer (Fig. 8). The outer electron-dense layer had a fuzzy surface (Fig. 8).

Beneath the sporocyst wall, and surrounding the sporozoites, lay electron-dense material (Figs. 4 \& 6). Each sporozoite contained marginated and clumped nuclear material (a nucleolemma was not seen), and a large, homogenous, medium electron-dense structure, tentatively identified as the refractile body (Figs. $9 \& 10$ ). In some sections, a cluster of amylopectin granules was seen (Fig. 11). An apical complex was not identified, although 1 sporozoite contained narrow, electron-dense, structures tentatively identified as micronemes (Fig. 9).

Oocysts and sporocysts were irregularly shaped, suggesting suboptimal fixation. Some cell membranes and internal organelles of the sporozoites were not clearly distinguished.

Only 1 other developmental stage, a macrogamontor possibly a zygote-was seen (Fig. 12). This spherical structure was characterized by numerous electronlucent inclusions, tentatively identified as amylopectin granules, and a single eccentric nucleus (Fig. 12). 

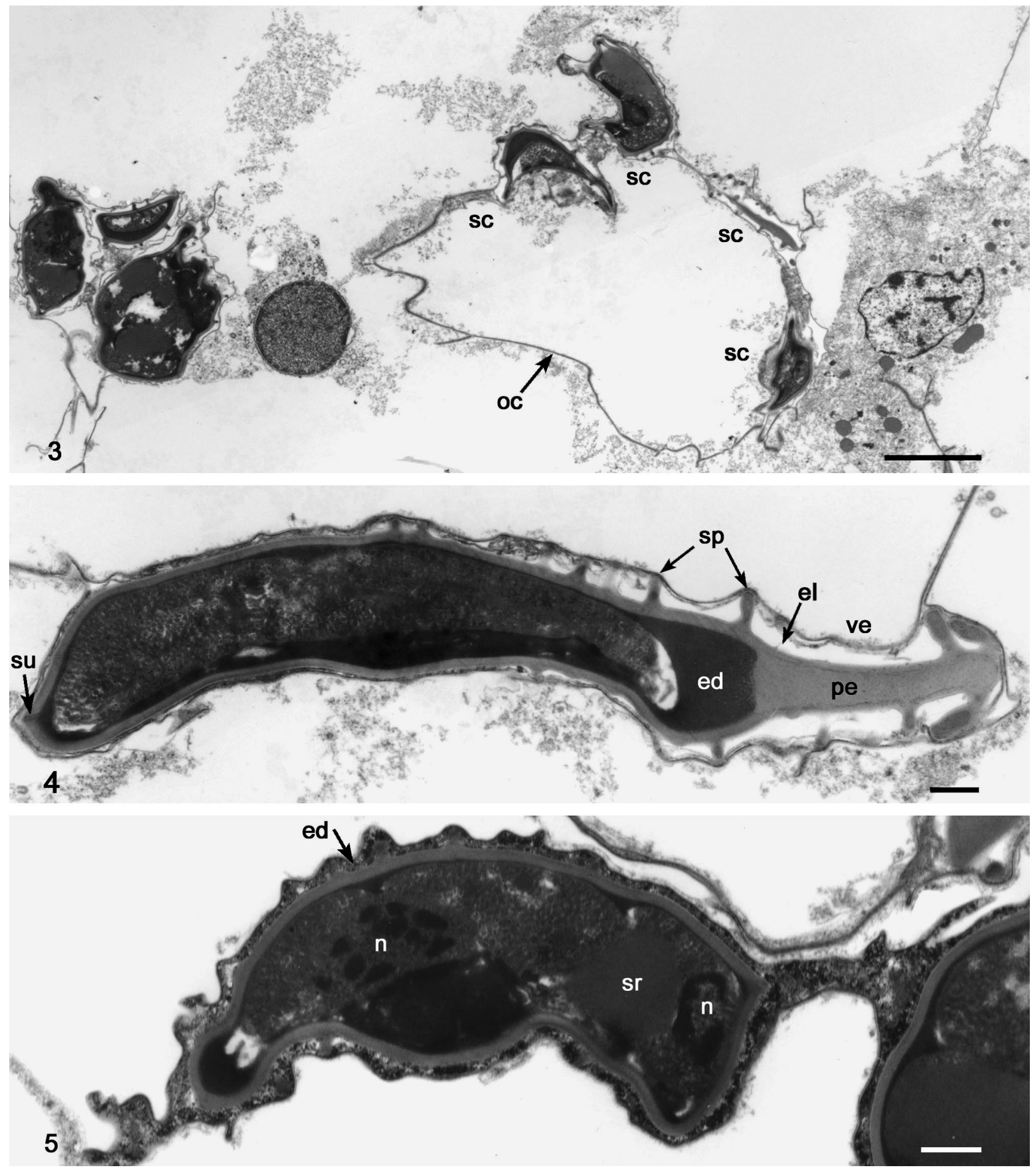

Figs. 3 to 5. Calyptospora sp. in liver of Arapaima gigas; transmission electron micrographs. Fig. 3. Oocyst (oc) containing 4 sporocysts (sc). Scale bar $=8 \mu \mathrm{m}$. Fig. 4 . Longitudinal section of a sporocyst covered with membranous veil (ve): posterior pole of the sporocyst narrows into long, approximately cylindrical extension (pe); cylindrical to club-shaped sporopodia (sp) are borne (perpendicular to the sporocyst surface) on this and adjacent posterior regions; note electron-lucent region (el) between veil and sporocyst, and electron-dense material (ed) beneath the sporocyst wall and surrounding the sporozoites. The suture (su) is visible at the broad anterior end of the sporocyst. Scale bar $=0.5 \mu \mathrm{m}$. Fig. 5. Sporocyst containing 2 sporozoites; note electron-dense, flocculent material (ed) between veil and sporocyst. The sporozoite contains marginated and clumped nuclear material (n) (a nucleolemma was not seen) and large, homogenous, medium electron-dense structure tentatively identified as the refractile body (sr). Scale bar $=0.5 \mu \mathrm{m}$ 

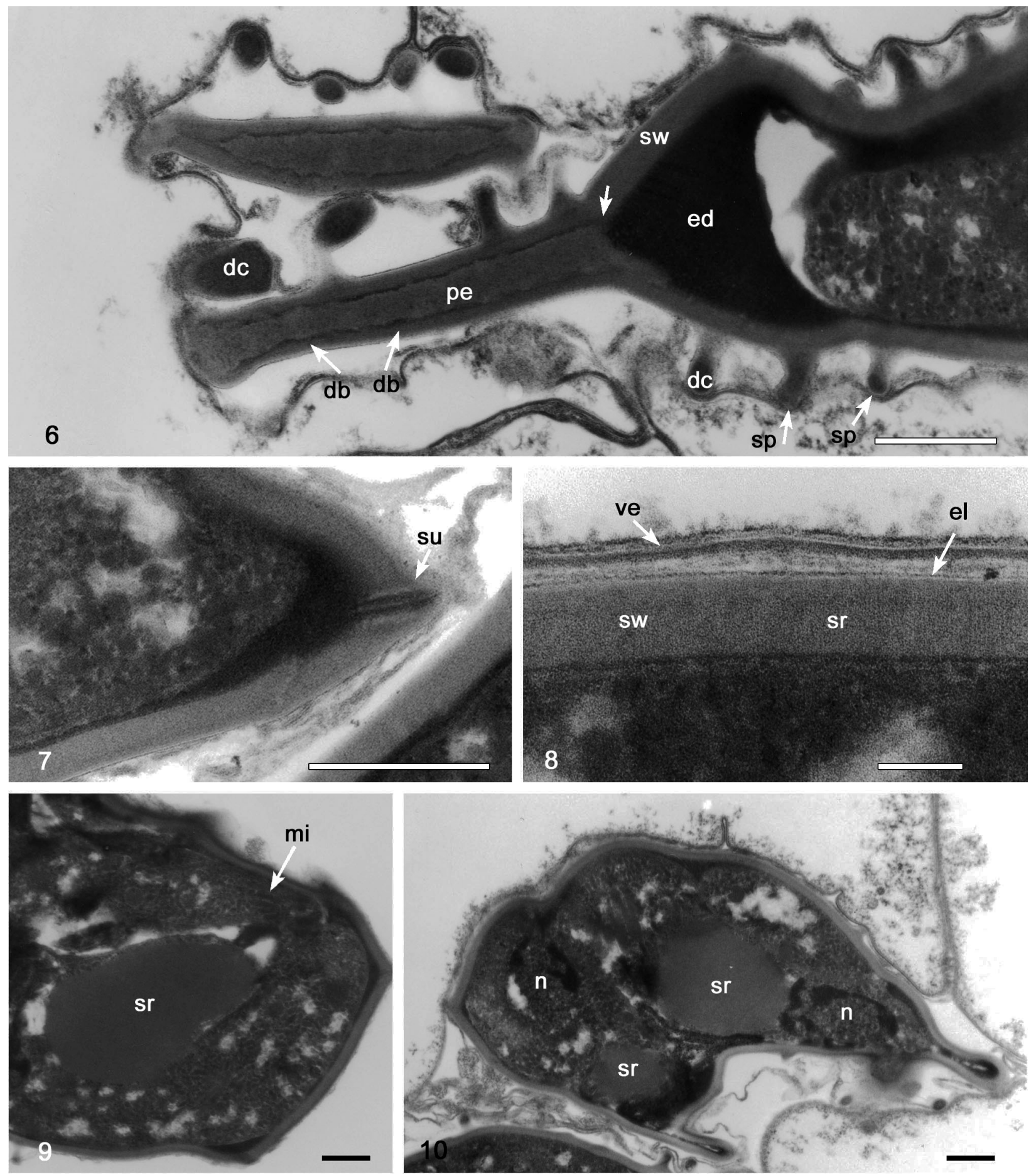

Figs. 6 to 10. Calyptospora sp. in liver of Arapaima gigas; transmission electron micrographs. Fig. 6. Posterior pole of the sporocyst showing narrowing of sporocyst wall into the long, approximately cylindrical extension (pe); extension is lined by thin lamella of electron-dense material (db), approximately $0.1 \mu \mathrm{m}$ beneath the surface; this lamella is possibly an extension (see arrow) of the electron-dense material (ed) that lies beneath the sporocyst wall (sw) and surrounds the sporozoites. The cylindrical to clubshaped sporopodia (sp) arise perpendicular to the sporocyst surface, are approximately $0.5 \mu \mathrm{m}$ long and $0.125 \mu \mathrm{m}$ wide, and contain an electron-dense core (dc). Scale bar $=0.5 \mu \mathrm{m}$. Fig. 7 . Details of sporocyst wall showing suture (su). Scale bar $=0.5 \mu \mathrm{m}$. Fig. 8. Veil (ve) and sporocyst wall (sw); the veil is tri-layered, with 2 electron-dense layers lying each side of an electron-lucent layer; outer electron-dense layer has a fuzzy surface. The sw is approximately $0.125 \mu \mathrm{m}$ thick, except where giving rise to the posterior pole and sporopodia. The wall consists of a thin outer electron-lucent layer (el), with an electron-dense coating, and a thick, inner more electron-dense layer, with fine, regular, transverse striations; sr: refractile body. Scale bar $=0.125 \mu \mathrm{m}$. Fig. 9 . Detail of sporozoite showing elongate structures tentatively identified as micronemes (mi). Note also large, medium electron-dense structure, possibly the refractile body $(\mathrm{sr})$. Scale bar $=0.5 \mu \mathrm{m}$. Fig. 10. Sporocyst containing 2 sporozoites, lying head to tail, as evidenced by opposite positions of nuclear material (n) and refractile bodies (sr). Scale bar $=0.5 \mu \mathrm{m}$ 

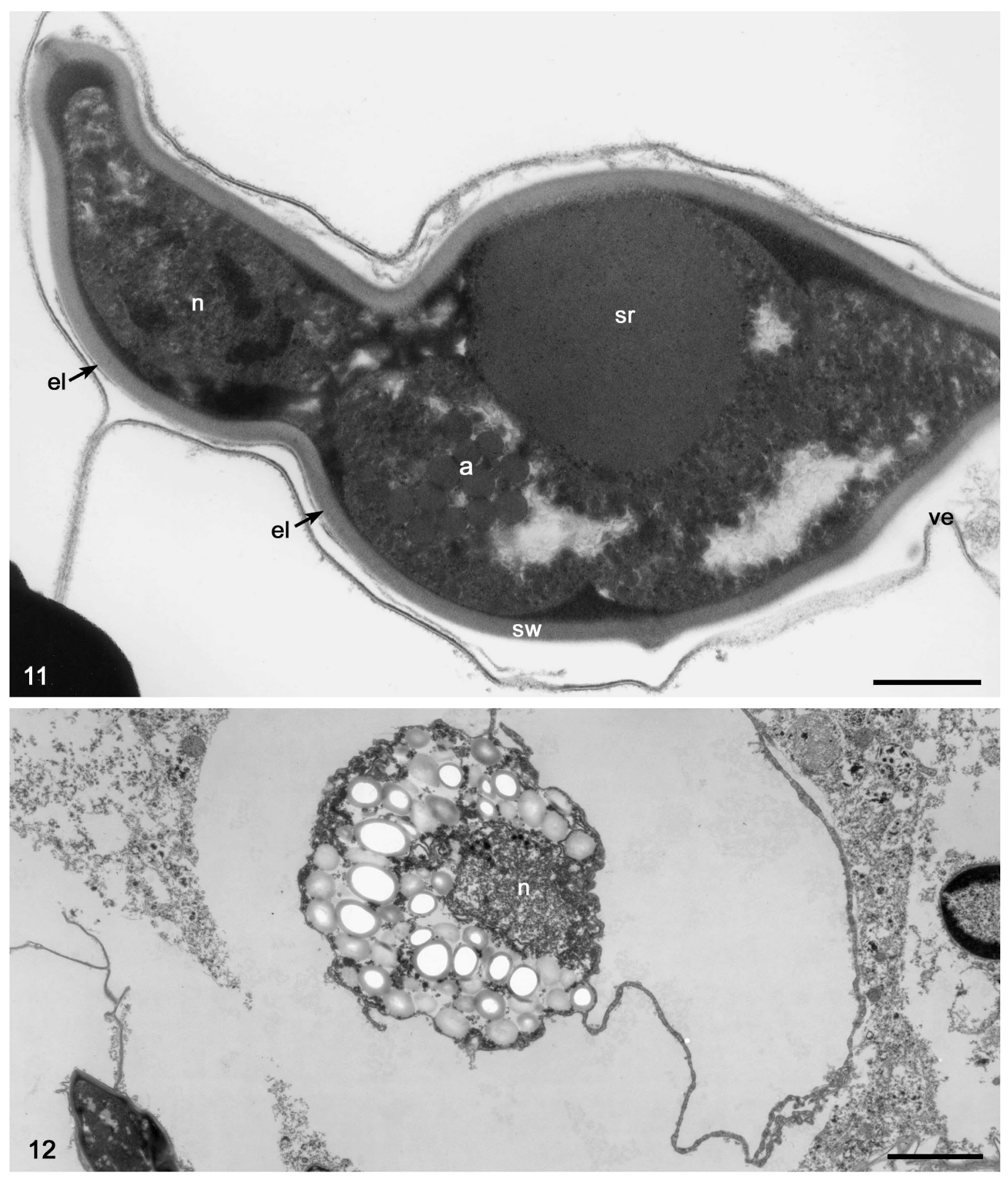

Figs. 11 \& 12. Calyptospora sp. in liver of Arapaima gigas; transmission electron micrographs. Fig. 11. Veil (ve) and sporocyst with 1 sporozoite in plane of section; the veil has a thin, moderately electron-dense, outer layer with a rough surface, narrow electronlucent middle layer, and a thicker, very electron-dense, inner layer. In the sporocyst wall, the outer electron-lucent layer (el) is clearly visible; within the sporozoite lies nuclear material (n), a large refractile body (sr) and amylopectin granules (a). The remainder of the cytoplasm is largely filled with flocculent material. Scale bar $=0.6 \mu \mathrm{m}$. Fig. 12. Macrogamont, or possibly a zygote, characterized by numerous electron-lucent structures (tentatively identified as amylopectin granules) and a single eccentric nucleus (n). Scale bar $=8 \mu \mathrm{m}$ 


\section{Deposition of material}

Histologic sections of liver from Arapaima gigas, stained with hematoxylin and eosin and with the ZiehlNeelsen acid-fast method, were deposited in the United States National Parasite Collection (USNPC), USDA, ARS, ANRI, Building 1180, BARC-East, 10300 Baltimore Avenue, Beltsville, MD 20705. Their accession number is USNPC 97631.

\section{DISCUSSION}

\section{Pathology}

Among the diversity of pathogens and lesions observed in the arapaima, the most significant were considered to be the coccidians in the liver. The monogenean-induced branchitis was relatively minor and was an incidental finding. Although we did not observe inflammation associated with Calyptospora sp. infection, the parasites replaced 15 to $33 \%$ of hepatic parenchyma, and may have led to hepatic insufficiency and contributed to the mortality.

Calyptospora (Eimeria) funduli in gulf killifish Fundulus spp. may replace up to $85 \%$ of the hepatic tissue, with minimal inflammatory response and occasional fibrotic encapsulation of small aggregates of protozoans (Solangi \& Overstreet, 1980). In the C. (E.) funduli infection, inflammatory infiltrates were first noticed at approximately Day 10 in experimentally infected fish, peaking around Day 18, and subsiding by Day 30 (Solangi \& Overstreet 1980). Since most of the arapaima we studied had died more than 14 mo after importation, it seems likely that if Calyptospora sp. behaves like $C$. funduli, the inflammatory response would have subsided prior to death and histologic examination

In Calyptospora serrasalmi infection in black piranha, proliferative lesions developed around the oocysts, with formation of granulomas, and clusters of oocysts were encapsulated by layers of host connective tissue (Cheung et al. 1986). Furthermore, the cytoplasm of infected hepatocytes was occupied by the oocysts displacing the host cell nucleus, which appeared condensed at the periphery of the cell. In C. tucunarensis infection in tucunare, severe degeneration of the liver has been reported; however, there were no inflammatory or necrotic changes (Békési \& Molnár 1991). Oocyst aggregations rarely elicited a host response, and only occasionally was a connective tissue capsule seen around older oocysts (Békési \& Molnár 1991).

We are unable to compare the pathology associated with Calyptospora sp. infection in the arapaima with that associated with $C$. empristica in starhead top- minnows (Fundulus notti) or E. (C.?) harpodoni in 'Bombay duck' Harpodon nehereus, since the latter 2 parasites have only been studied from morphological and, or, ultrastructural-rather than pathologicalaspects (Setna \& Bana 1935, Fournie et al. 1985).

\section{Spore morphology and identification of the protozoan}

The distinctive thin veil covering the sporocysts, which was supported by sporopodia (extensions of the sporocyst wall), is consistent with only 1 known genus of Apicomplexa that infects fish: Calyptospora (Overstreet et al. 1984).

Within the genus Calyptospora, 4 species have been described: C. empristica, C. funduli, C. serrasalmi, and C. tucunarensis; the parasite originally described as Eimeria harpodoni may also belong in the genus Calyptospora (Table 1). These species descriptions vary in their level of completeness. It is now recognized that comprehensive descriptions must include morphometrics derived from oocysts in fresh (wet) preparations (Bandoni \& Duszynski 1988), and while this information is available for C. empristica, C. funduli, C. tucunarensis and E. harpodoni, the type description of $C$. serrasalmi was based only upon acidfast, air-dried smears. Nonetheless, we were able to undertake comparison of some aspects of the morphometrics of the Calyptospora parasite from Arapaima gigas with each of the aforementioned species of Calyptospora (Table 1). Emphasis was placed on the shape and adornment of the sporocysts, since the appearance of these features would only be minimally affected by type of sample.

The Calyptospora sp. from the arapaima is easily distinguishable from C. empristica and C. funduli, both of which infect cyprinodont fishes in North America (Duszynski et al. 1979, Fournie et al. 1985). C. empristica has an ellipsoid sporocyst bearing 1 long sporopodium (5 to $7 \mu \mathrm{m}$ long) at the narrow pole that is adorned with lateral projections $0.5 \mu \mathrm{m}$ long and that terminate in knob-like swellings (Fournie et al. 1985). The ornamented region of the sporocyst of $C$. empristica resembles the rostrum of a sawfish. C. funduli has an ovoid sporocyst bearing sporopodia over its entire surface (Duszynski et al. 1979). Calyptospora sp. from arapaima was readily distinguished from Eimeria harpodoni (which may belong to the genus Calyptospora); E. harpodoni has a V-shaped appendage at the pointed end of the sporocyst (Setna \& Barna 1935).

Prior to comparing Calyptospora sp. from arapaima with C. serrasalmi and C. tucunarensis, we recognized that in our new examinations of the latter 2 species, we were able to see features of the sporopodia number and distribution that were either not seen 
by the original investigators, or were not reported in the type descriptions. For C. serrasalmi, re-examination of the type material (acid-fast stained, air-dried smears) revealed that numerous sporopodia are indeed present on the narrow posterior end of the pyriform sporocyst, and approximately 25 to $30 \%$ of the length of the sporocyst is adorned. In the type description, only 8 to 10 sporopodia were reported, and they were illustrated as arising only laterally from, but not all round, 15 to $20 \%$ of the posterior end of the sporocyst. For C. tucunarensis, we prepared new histological sections stained with ZiehlNeelsen acid-fast, and now report, for the first time, the presence of numerous sporopodia over the posterior end of the pyriform sporocysts; approximately 20 to $25 \%$ of the length of the sporocyst was adorned. In the type description, only 1 sporopodium (which could be interpreted as a posterior elongation of the main sporocyst wall) was described for C. tucunarensis (Békési \& Molnár 1991). However, the type description of $C$. tucunarensis was based on sporulated oocysts in fresh preparations, with supplementary descriptions from sectioned material stained with hematoxylin and eosin. The original investigators did not use the Ziehl-Neelsen acid-fast method (which stains the sporocysts), and hence, some fine details such as small sporopodia were not seen.

Thus, we have shown that 3 species of Calyptospora (C. serrasalmi, C. tucunarensis, and Calyptospora sp. from arapaima) all have pyriform sporocysts bearing sporopodia on the posterior narrow pole, with approximately $25 \%$ of the length of the sporocyst being adorned. In order to investigate possible synonymy among these species, new comprehensive descriptions are needed for C. serrasalmi and Calyptospora sp. from arapaima, based on morphology and mophometrics of fresh material, including oocysts.

There were differences in the distribution of the sporulated oocysts of different Calytopsora species in the sections of liver tissue of the different host fishes. Sporulated oocysts occurred singly or in packets in $C$. empristica (Fournie et al. 1985), in groups (in heavy infections) in C. funduli (Hawkins et al. 1983), and were clustered in C. serrasalmi (Cheung et al. 1986) and (when mature) in C. tucunarensis (Békési \& Molnár 1991), whereas in Calyptospora sp. in arapaima, the sporulated oocysts were scattered throughout the liver tissue.

\section{Ultrastructure of Calyptospora sp. from arapiama}

Transmission electron microscopy studies confirmed the morphology of the structures seen with the light microscope, and allowed further comparison of the
Calyptospora sp. from arapaima with C. empristica and C. funduli, the only 2 species of Calyptospora that have been previously studied ultrastructurally.

In comparing the fine structure of these 2 species with that of the one we now describe as Calyptospora sp., we note that different authors use different terminology to describe the projections from the sporocyst surface that are so distinctive for this genus. In $C$. empristica, the very elongated structure at the posterior pole is referred to as the sporopodium by Fournie et al. (1985), and the numerous lateral projections with knob-like terminal swellings upon it are not afforded a particular morphological descriptor by Fournie et al. (1985). However, the lateral projections of C. empristica are of similar appearance to the numerous small projections arising directly from the main sporocyst wall of $C$. funduli and referred to as sporopodia by Hawkins et al. (1983). We, therefore, wish to resolve such confusion by proposing that the term 'sporopodia' be used for the multiple small projections from the sporocyst wall, and not for the larger, posterior extension of the sporocyst wall.

Preliminary data suggest that the distribution, shape and internal structure of the multiple small projections (which we now define as sporopodia) can be used as a robust taxonomic feature. Sporopodia are present only on the elongate posterior projection of Calyptospora empristica, irregularly cover the entire ovoid sporocyst of $C$. funduli, and cover the posterior projection and adjacent regions of the main part of the pyriform sporocyst in C. tucunarensis, C. serrasalmi, and Calyptospora sp. from arapaima (Duszynski et al. 1979, Fournie et al. 1985, present paper respectively). The tips of the sporopodia of C. empristica are knob-like, in C. funduli a T-mushroom shape, and in Calyptospora sp. from arapaima slightly broadened. In both $C$. empristica and $C$. funduli, the internal structure of the sporopodia is the same as that of the sporocyst wall, except that striations are lacking in the sporopodia; in Calyptospora sp. from arapaima, the sporopodia are more electron-dense than the sporocyst wall and also lack striations.

The appearance of the 3-layered veil and the 2layered sporocyst wall appears similar in Calyptospora empristica, C. funduli and Calyptospora sp. from arapaima.

Despite the examination of numerous sporocysts, the apical opening reported for other species in this genus was not seen. This may have been due to a lack of sections in the correct orientation, although it is also possible that such an opening is not present in the species we now describe. We are, nonetheless, confident of the placement of the parasites we observed in the genus Calyptospora, because the presence of an apical opening does not form part of the genus description in 
the most recent edition of the Illustrated Guide to the Protozoa (Perkins et al. 2000).

We were unable to see fine details of the sporozoites and the other contents of the sporocysts, and this may have been at least partly attributable to the fact the our samples were initially prepared for light microscope studies, and were subsequently deparaffinized and processed for electron microscopy. However, other authors (Duszynski et al. 1979, Hawkins et al. 1983, Fournie et al. 1985) have noted that the oocysts of Calyptospora funduli are resistant to fixation.

\section{Host and geographic records}

We believe this to be the first report of the genus Calyptospora from Arapaima gigas and the family Osteoglossidae. Previous reports of this genus have been from hosts in the families Charcidae, Cichlidae and Cyprinodontidae (and possible also Synodontidae) (Table 1): Two Calyptospora species have previously been reported from South American fishes, C. serrasalmi from black piranha (Characidae) captured in the Amazon and held at the New York aquarium (Cheung et al. 1986), and C. tucunarensis from wild and farmed tucunare (Cichlidae) from Brazil (Békési \& Molnár 1991). If C. serrasalmi, C. tucunarensis and the Calyptospora species we now describe are subsequently shown to be synonymous, this would mean that this parasite has an unusually wide host range for a coccidian (infecting hosts of 3 different orders).

The coccidian fauna, particularly the eimeriorinids, of neotropical fishes appears to be less diverse that that of fishes from other regions, with a single genus (Calyptospora) reported from the former (Thatcher 1991) and as many as 7 genera (Calyptospora, Crystallospora, Eimeria, Epieimeria, Goussia, Isospora and Octosporella) reported from other regions of the world (Lom \& Dykova 1992, Hoffman 1999). Currently, only 4 of these genera are recognized as valid, with Crystallospora, Epieimeria and Goussia considered junior synonyms of Eimeria (Perkins et al. 2000). However, at present, we do not know if the eimeriorinid fauna of neotropical fishes is truly sparse, or whether there is a scarcity of taxonomic studies on these parasites and hosts.

The monogenean Dawestrema cycloancistrium has previously been recorded from Arapaima gigas from Brazil (Thatcher 1991). The nematodes seen in histological section of the serosa of the intestine were not identified to genus and species in our study; however, at least 4 taxa of nematodes have previously been reported from Arapaima gigas (Thatcher 1991). Of these, Camallanus, Goezia and Porrocaecum are parasites of the digestive tract and may, therefore, have been the parasite we observed.

\section{Life cycle and development}

Based on what has been experimentally demonstrated for Calyptospora funduli (Fournie et al. 1983), supported by investigations on $C$. empristica (Fournie et al. 1985), and considered a diagnostic criterion for the genus (Overstreet et al. 1984), Calyptospora sp. from arapaima probably has an indirect (heteroxenous) life cycle. The fish serves as the final host, with sporulated oocysts in the liver, and crustaceans such as shrimp serve as intermediate hosts (Fournie et al. 1985). Palaemonetes sp. and Macrobrachium spp. shrimp can serve as intermediate hosts for $C$. funduli (Lom \& Dykova 1992).

In the killifish, disease associated with Calyptospora funduli could not be experimentally produced without feeding infected grass shrimp. Attempts at infection by feeding sporulated oocysts or infected fish livers were unsuccessful, even when made periodically over a 6 mo period. Feeding infected grass shrimp, however, produced disease in $15 \mathrm{~d}$. Therefore, it seems likely that these arapaima acquired Calyptospora sp. infection after eating infected, small, invertebrate intermediate hosts when young, and not from a diet of goldfish Carassius auratus or guppies Poecilla poecilla as juveniles while in captivity. These arapaima had specifically not been fed grass shrimp in the captive holding facilities in Manaus, Florida, or New York because the aquarists were concerned about the potential for self-trauma on the chitinous shells (J. McCarthy pers. comm.). Grass shrimp-like crustaceans are known to occur in the streams and pools where these fish were collected (A. Schwartz pers. comm.). Thus, it appears that this infection was acquired by these fish in their natural environment.

A 2-host life cycle for Calyptospora in arapaima is further supported by our observations of both sporulated oocysts and macrogamonts (or possibly zygotes), thus indicating that sporogony and gametogony took place in the fish (as is known for C. funduli, in which a 2-host life cycle has been experimentally demonstrated; Solangi \& Overstreet 1980, Upton \& Duszynski 1982). In the arapaima, pre-sporogonic stages were rarely encountered, (and merogony was not seen), also consistent with infection being acquired as wild juveniles, with the subsequent period in captivity allowing these stages to mature to sporulated oocysts, with no further acquisition of infection.

It is of interest that Overstreet et al. (1984) proposed that the family Calyptosporidae, with a 2-host life cycle, is more primitive than the family Eimeriidae that has 1-host life cycle. Calyptospora sp. may be a relatively ancient parasite, and have a long association with arapaima. 


\section{CONCLUSIONS}

This is the first description of Calyptospora sp. in arapaima. Calyptospora sp. and Dawestrema sp. infections probably contributed to the mortality of the captive arapaima. Further studies on Calyptospora sp. in tropical fishes such as arapaima are needed to further characterize the organism's life cycle as well as potential prophylaxis and treatment regimes. The economic and conservation value of arapaima warrant such studies.

Acknowledgements. We are most grateful to Dr. K. Molnar of the Veterinary Medical Research Institute, Budapest, Hungary, for graciously loaning the type material of Calyptospora tucunarensis, and to Dr. D. C. Kritsky for identification of the Dawestrema. Mr. J. McCarthy of Long Island Aquatics, Long Island, New York and Mr. A. Schwartz of International Fisheries, Miami, Florida, provided invaluable information on the history of these arapaima. Mr. J. Prappas, former Curator of Moody Gardens, Galveston, Texas, and pathologist P. Varner kindly provided us with 1 case, and its paraffin blocks, for special stains. We thank Mr. J. Jenkins of the Department of Veterinary Pathology, Armed Forces Institute of Pathology, for his meticulous preparation and examination of the ultrastructural samples. We also thank Mr. A. Morataya for photographic support.

\section{LITERATURE CITED}

Bandoni SM, Duszynski DW (1988) A plea for improved presentation of type material for coccidia. J Parasitol 74: 519-523

Békési L, Molnár K (1991) Calyptospora tucunarensis n.sp. (Apicomplexa: Sporozoa) from the liver of tucunare Cichla ocellaris in Brazil. Syst Parasitol 18:127-132

Casares M, Arevalo M-A, Fernandez E (2002) Notes on the husbandry of the arapaima Arapaima gigas, at 'Faunia', Madrid. Zool Garten NF 72:238-244

Cheung PJ, Nigrelli RF, Ruggieri GD (1986) Calyptospora serrasalmi, sp. n. (Coccidia: Calyptosporidae) from liver of

Editorial responsibility: Wolfgang Körting,

Hannover, Germany the black piranha, Serrasalmus niger Schomburgk J Aquaricult Aquat Sci 4:54-57

Duszynski DW, Solangi MA, Overstreet RM (1979) A new and unusual eimerian (Protozoa: Eimeriidae) from the liver of the Gulf killifish, Fundulus grandis. J Wildl Dis 15:543-552

Fournie JW, Solangi MA, Overstreet RM (1983) True intermediate hosts for Eimeria funduli (Apicomplexa) from estuarine fishes. J Protozool 30:672-675

Fournie JW, Hawkins WE, Overstreet RM (1985) Calyptospora empristica nov. sp. (Eimeriorina: Calyptosporidae) from the liver of the starhead topminnow, Fundulus notti. J Protozool 32:542-547

Hawkins WE, Fournie JW, Overstreet RM (1983) Organization of sporulated oocysts of Eimeria funduli in the Gulf killifish, Fundulus grandis. J Parasitol 69:496-503

Hoffman GL (1999) Parasites of North American freshwater fishes, 2nd edn. Cornell University Press, Ithaca, NY

Kritsky DC, Boerger WA, Thatcher VE (1985) Neotropical monogenea. 7. Parasites of the Pirarucu, Arapaima gigas (Cuvier), with descriptions of two new species and redescription of Dawestrema cycloancistrium, Price and Nowlin, 1967 (Dactylogyridae; Ancyrocephalinae). Proc Biol Soc Wash 98:321-331

Lom J, Dykova I (1992) Protozoan parasites of fishes. Elsevier, Amsterdam

Overstreet RM, Hawkins WE, Fournie JW (1984) The coccidian genus Calyptospora n.g. and family Calyptosporidae, n. fam. (Apicomplexa), with members infecting primarily fishes. J Protozol 31:332-339

Nelson JS (1984). Fishes of the world, 2nd edn. Wiley Interscience, New York

Perkins FO, Barta JR, Clopton RE, Pierce MA, Upton SJ (2000) Phylum apicomplexa. In: Lee JJ, Leedale GF, Bradbury P (eds) An illustrated guide to the Protozoa, 2nd edn. Society of Protozoologists, Lawrence, KS, p 190-369

Setna SB, Bana RH (1935) Eimeria harpodoni n. sp., a new coccidium from Harpodon nehereus (Ham. \& Buch). J R Microsc Soc (Trans) 55:256-260

Solangi MA, Overstreet RM (1980) Biology and pathogenesis of the coccidium Eimeria funduli infecting killifish. J Parasitol 66:513-526

Thatcher VE (1991) Amazon fish parasites. Amazonia 11: 263-572

Upton SJ, Duszynski DW (1982) Development of Eimeria funduli in Fundulus heteroclitus. J Protozool 29:66-71

Submitted: January 18, 2005; Accepted: October 24, 2005 Proofs received from author(s): April 4, 2006 